\title{
Minimisation of Overestimation of River Flows in 1D- Hydrodynamic Modeling
}

\section{Komal Vashist}

National Institute of Technology Kurukshetra

K. K. Singh ( $\sim$ k_k_singh_2000@yahoo.com )

National Institute of Technology Kurukshetra https://orcid.org/0000-0003-4374-7713

\section{Research Article}

Keywords: River Flow, River Cross-section, SRTM DEM, MIKE HYDRO \& Manning's Roughness Coefficient

Posted Date: July 26th, 2021

DOI: https://doi.org/10.21203/rs.3.rs-654833/v1

License: (c) (i) This work is licensed under a Creative Commons Attribution 4.0 International License. Read Full License 


\title{
MINIMISATION OF OVERESTIMATION OF RIVER FLOWS IN 1D- HYDRODYNAMIC MODELING
}

Komal Vashist

PhD Research Scholar

Email: vashistkoma194@gmail.com
K. K. Singh

Professor

Email:k_k_singh_2000@yahoo.com

Department of Civil Engineering, NIT Kurukshetra, India,

\begin{abstract}
One-dimensional hydrodynamic models overestimate river cross-section derived from freely available SRTM DEMs. The present study aims to minimize the overestimation of river flow. DEM-extracted cross-sections obtained from $30 \mathrm{~m}$ and $90 \mathrm{~m}$ resolutions show higher elevation values than the actual river cross sections of Krishna and Bhima rivers, India. To minimize the overestimation of the river flow, DEM-extracted cross-sections are modified using known cross-section of the river. The corrections for cross sections extracted from DEM, are obtained by subtracting the DEM-derived cross-sections from a known cross-section of the river. Monsoons flows that occurred in years 2006 and 2009 in Krishna and Bhimariver have been used for modeling. The MIKE HYDRO River model performance with modified DEM-extracted cross-sections of river improves as the correlation coefficient, root mean square error, index of agreement, Nash Sutcliffe efficiency \& Percentage deviation in peak $(\%)$ values are improved.
\end{abstract}

KEYWORDS: River Flow; River Cross-section; SRTM DEM; MIKE HYDRO \& Manning's Roughness Coefficient

\section{INTRODUCTION}

Among the natural hazards (cyclones, floods, landslides, drought, volcanic eruptions, and earthquakes) occurring in developing countries, flood is the most prominent for study as it 
is the most frequent disastrous event. Many a time, it causes a heavy toll on human lives, loss to economy, geographical and geological damage to the locality. India is one of the worst flood-affected countries and the Himalayan Rivers have a large contribution in causing floods in different states. The main causes of floods in India are due to overtopping of river banks because of sedimentation and low carrying capacity, heavy precipitations, rise in water level due to cyclones and high tides, poor drainage, and management practices. To minimize the devastation caused by floods, information of the disastrous event for improving decision making, planning design, and construction activities in the flood-prone areas plays a vital role. Such information can be inferred from the mathematical modeling which simulates the spatial and temporal characteristics of the flood events.

Various numerical models are used by researchers for floodplain delineation, flood inundation modeling, flood hazard mapping, hydrodynamic modeling, flood zone mapping. (Bates et al. (1995); Farooq et al. (2019); Horritt \& Bates (2001, 2002); Tehrani et al. (2020); Kadam \& Sen (2012); Patro et al. (2009); Pramanik et al. (2010); Sahoo \& Sreeja (2017); Teng et al. (2017); Wright et al. (2008)). The flood inundation models can be classified based on spatial extent (lumped or distributed), dimensionality (1D, 2D, 3D), or mathematical complexity (dynamic wave, diffusive wave, inertial wave models, etc.) (Nkwunonwo et al., 2020). These models can be hydrodynamic models, empirical models, or conceptual models (Afshari et al. (2018); Geravand et al. (2020); Teng et al. (2017)).

One-dimensional hydrodynamic models like HEC-RAS, ISIS 1D, MIKE 11, MIKE HYDRO River, SOBEK, TUFLOW 1D, are the simplest ones and require less computation time and effort but does not give good results with complex rivers. These models simulate 
the channel and floodplain as a series of lateral-sections perpendicular to the flow direction and solve either the complete or some approximation of the one-dimensional shallow water equations (SWEs) (Bates \& Roo (2000)). 2D models solve the two-dimensional SWEs using the method of characteristics, finite element, or finite difference method. Models such as DIVAST, HEC-RAS 2D, ISIS 2D, JFLOW, LISFLOOD-FP, MIKE 21, RMA2, SOBEK 2D, TELEMAC 2D, TUFLOW 2D require an accurate representation of bathymetry, higher computational cost, and time (Horritt \& Bates (2002); Mignot et al. (2006)) but with the advancement of remote sensing technology, these models are gaining popularity (Bates (2004)). 3D models such as DELFT 3D, MIKE 3, TELEMAC 3D, TUFLOW 3D are complex and have high data requirements than the simpler models giving realistic results ( Hunter et al. (2007)). Also, there are 1D/2D coupled models used in literature like MIKE FLOOD, MIKE URBAN, SOBEK Suite, TUFLOW Classic used by researchers (Fan et al. (2017); Kadam \& Sen (2012); Lin et al. (2006); Patro et al. (2009)) for flood inundation modeling. One of the advantages of hydrodynamic models is that they have a direct linkage to hydrology and can account for hydraulic features and structures.

There is difficulty in hydrodynamic modeling in developing countries because of the lack of data availability. The problem is encountered because of the non-availability of the highresolution digital elevation models (DEMs), cross-section data, and a suitable set of data for calibration and validation. 1D models can simulate accurately because of the accuracy of describing the hydraulic behavior of streams and rivers (Chen \& Liu, 2017). Also, if high-resolution data is available 1D models are able to perform very well in larger stream domains (Bates (2004)). So the need has arisen for using high-resolution DEMs because low-resolution DEMs have the limitation of dropping out important features that affects 
fluid dynamics (Cook \& Merwade (2009); Marks \& Bates (2000); Omer et al. (2003); Werner (2001)).

As the hydrodynamic modeling results (e.g. Yu and Lane, 2006, Horritt et. al. 2006) depend on the spatial resolution of DEM, one-dimensional hydrodynamic models overestimate simulated river level due to inherent overestimation of elevation of riverbed cross-section derived from freely available SRTM DEMs. Thus, the present study tries to minimise this overestimation of river flow using MIKE HYDRO river. To perform 1D hydrodynamic modeling, on the available data set (pertaining to the Krishna and Bhima River) MIKE HYDRO River model was chosen because of less complexity of the river system, and less computational time. In 2009 heavy rain caused a flash flood in the north Karnataka and Rayalaseema region of Andhra Pradesh that affected nearly 2 million people and claimed 210 lives (Padmanabhan, 2009). The total cost of damage was estimated to be Rs. 128446.8 million (APWRDC 2009). Various districts of Karnataka (Bijapur, Gulbarga, Raichur) and Andhra Pradesh (Mahbubnagar and Kurnool) were the ones worst affected by the flood.

\section{MATERIALS AND METHODOLOGY}

\section{Study area}

In Peninsular India, Krishna Basin is the second-largest eastward draining interstate river basin that lies between the longitudes $73^{\circ} 21^{\prime} 00^{\prime}$ 'E and $81^{\circ} 09^{\prime} 00^{\prime}$ 'E and the latitudes $13^{\circ}$ 07'00' $\mathrm{N}$ and $19^{\circ} 25^{\prime} 00^{\prime} \mathrm{N}$ in the Deccan Plateau of states Maharashtra, Karnataka, Telangana, and Andhra Pradesh (Figure 1). Krishna river basin covers an area of 2.5 lakh $\mathrm{km}^{2}$, which amounts to nearly $8 \%$ of the total topographical area of India. The major contribution to the Krishna basin is by the states of Karnataka, Andhra Pradesh, and 
Maharashtra. The Krishna River originates in the Western Ghats and carries water discharge from the adjacent areas and finally drops discharge to the Bay of Bengal. It is one of the longest rivers in India with a length of around $1400 \mathrm{~km}$. In the states of Telangana and Andhra Pradesh, the Krishna River while covering a distance of $612 \mathrm{~km}$ covers a drainage area of 76,252 sq. km. Similarly, in Karnataka, it covers a drainage area of 1, 13, 271 sq. $\mathrm{km}$ with a length of merely $483 \mathrm{~km}$. In Maharastra, the length of the river is $306 \mathrm{~km}$ with a drainage area of 69,425 sq. $\mathrm{km}$. The major right bank tributaries of the Krishna River are Ghataprabha, Malaprabha, and Tungabhadra, and the major left bank tributaries are Bhima, Musi, and Munneru. The Tungabhadra after collecting water from nearby areas of

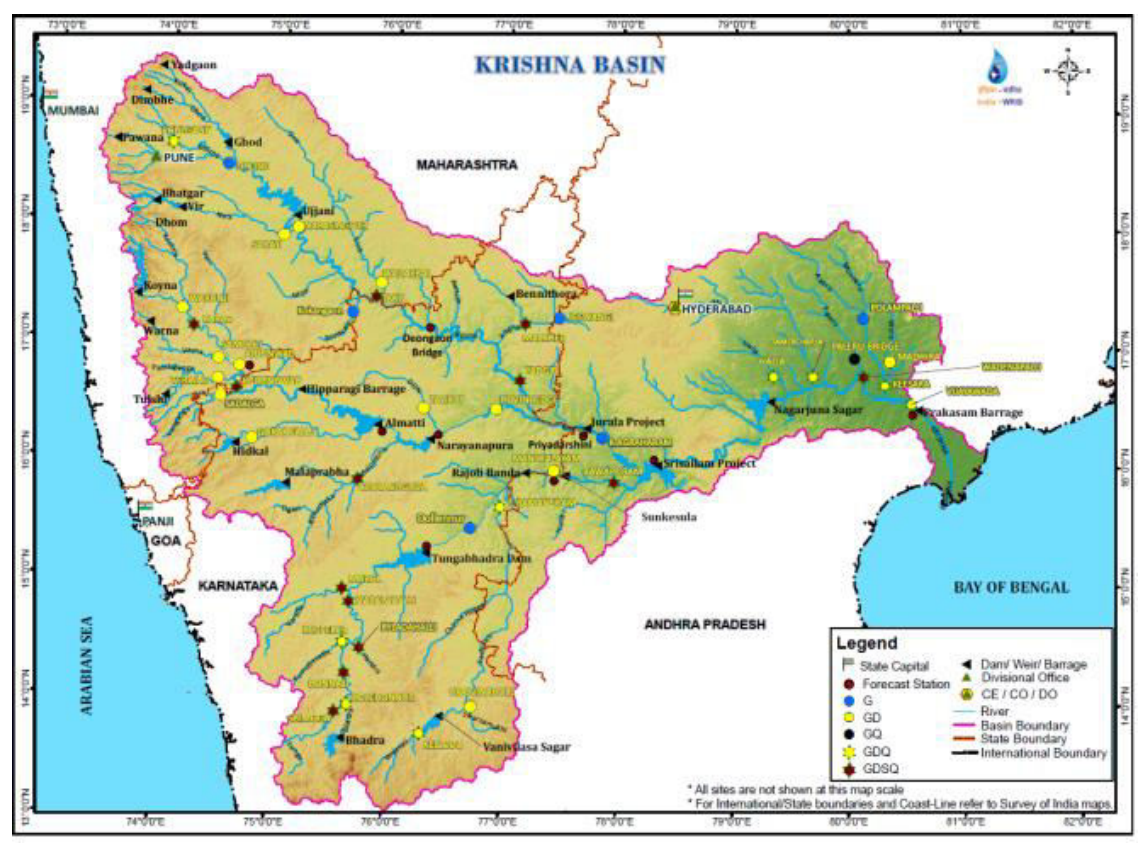

Figure 1. Krishna River Basin Map (Source: Krishna Basin Profile published by CWC) 


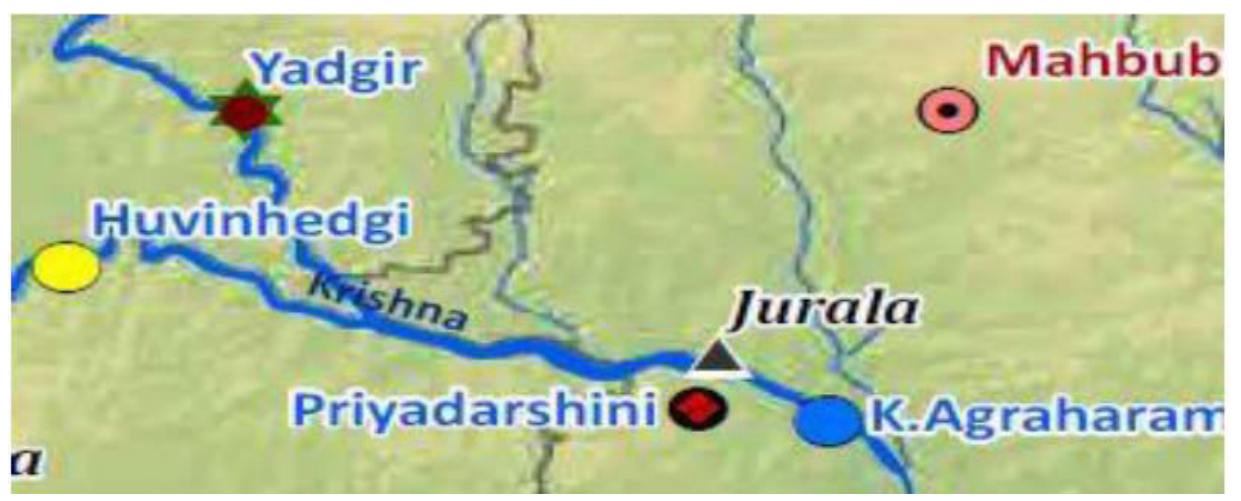

Figure 2. Study Area

approximately 71 thousand sq. $\mathrm{km}$ contributes the most to the Krishna River, whereas the longest river in terms of length of flow contributing to the Krishna River is Bhima. In this study, the station Huvinhedgi (76 55 '23' 'E, 16 29'28' 'N) on Krishna River was considered as the upstream boundary condition (Krishna at $0.0 \mathrm{~km}$ chainage). A Stretch of the Bhima river from Yadgir $\left(77^{\circ} 07^{\prime} 31^{\prime}\right.$ 'E, $16^{\circ} 44^{\prime} 15^{\prime}$ 'N) to its confluence with the Krishna river was considered for this study. Yadgir station and Krishna Agraharam (K. Agraharam) (78 11'47' 'E, $15^{\circ} 55^{\prime} 13^{\prime}$ 'N) station on Krishna River have been considered as the boundary condition for the study (Figure 2). From Huvinhedgi station to K. Agraharam station the river had a total length of $178 \mathrm{~km}$.

\section{Data used}

The data used in this study for hydrodynamic modeling in MIKE Hydro (River) are DEMs, discharge and water level time series at gauging stations, and published data related to flood in the study area. Time series files of discharge and water level for the years 2006 and 2009 for Huvinhedgi and Krishna Agraharam station of Krishna River and Yadgir station of Bhima River for monsoon period were procured from Krishna Godavari Basin 
Organization (KGBO) Central Water Commission (CWC) Hyderabad, Telangana, India. For the open end boundaries in the model, at the upstream boundaries a discharge file was supplied, and a constant water level was specified as the $\mathrm{d} / \mathrm{s}$ boundary condition. The discharge and water level data collected from CWC were represented as observed data in this study and the data predicted by the model were referred to as simulated data.

The SRTM (Shuttle Radar Topographic Mission) DEM of the study area of $30 \mathrm{~m}$ and $90 \mathrm{~m}$ resolution were downloaded from www.csi.cgiar.org and https://earthexplorer.usgs.gov (Reston, 1993) These downloaded files were made mosaic to get the complete DEM of the study area. The downloaded DEM needed to be preprocessed first to fill the voids and then used for tracing of rivers and extraction of cross-sections for the study.

\section{METHODOLOGY}

\section{Extraction of cross-sections from DEM}

River cross-sections are of prime importance for the hydrodynamic modeling of a river. Cross-sections of the Krishna and Bhima Rivers were extracted from the DEMs. These DEMs were projected at the topographic map at projection system GCS-WGS-1984 and all the digital elevation data were preprocessed before extracting cross-section. Rivers were added in the model using the add trace option available for digitizing the rivers keeping the topographic map of the study area as the base map. Cross-sections were then generated at an interval of $2000 \mathrm{~m}$ for the Krishna and Bhima Rivers using the cross-section generation tool in MIKE HYDRO. Coordinates of the extracted cross-sections and hydraulic parameters of the cross-sections like hydraulic radius, conveyance, Manning's coefficient are specified under the raw data option and processed data option respectively in the crosssection tab in MIKE HYDRO. In this study, the values were kept constant for all cross- 
sections to reduce the complexity of the study. Properties of all the extracted cross sections like move markers, resistance type, distribution, radius type, etc. of both the rivers are updated from the edit multiple cross-section option. The extracted cross-sections were corrected with respect to the cross-section available at K. Agrahatam station to obtain improvements in results.

\section{D Model set up}

MIKE HYDRO is a one-dimensional hydrodynamic model and an integrated modeling shell developed by the Danish Hydraulic Institute (DHI) for catchments, rivers, and floodplains (DHI 2017). MIKE HYDRO Basin and River module are the latest additions to the modeling of river flow using MIKE HYDRO (DHI, 2017). Basin module is used for a variety of tasks including management and planning of water resources within a basin and provides a flexible and computationally soft framework for many other applications. The MIKE HYDRO River module is used to solve the one-dimensional flow model for the river, which is essential for a large diversity of problems (DHI 2017).

The dynamic model employed in MIKE HYDRO solves the Saint Venant equations, as given by equation (1) and (2) using an implicit, finite-difference scheme (Abbott \& Ionescu, 1967):

$\frac{\partial Q}{\partial X}+\frac{\partial A}{\partial t}=q$

$\frac{\partial Q}{\partial t}+\frac{\partial\left[\Upsilon \frac{Q^{2}}{A}\right]}{\partial X}+g A \frac{\partial H_{1}}{\partial X}+\frac{g Q|Q|}{c^{2} A R}=0$

Where: - 
$\mathrm{Q}=\quad$ Discharge in cubic meter/second

$A=\quad$ Area in sq. meter

$\mathrm{q}=$ Lateral inflow in meter $^{2} /$ second

$\Upsilon=$ Momentum distribution coefficient

$\mathrm{g}=\quad$ Acceleration due to gravity in meter $^{2} /$ second

$H_{1}=$ Stage above the datum

$c=$ Chezy's roughness coefficient in meter ${ }^{1 / 2} /$ second

$\mathrm{R}=$ Hydraulic radius in meter

$\mathrm{X}=$ Longitudinal distance (in direction of flow)

$\mathrm{t}=\quad$ Elapsed time.

\section{Performance indices}

For evaluating the model performance, various performance indices were used in the literature. In this study, the hydrodynamic model has been evaluated by different performance metrics i.e; Correlation coefficient, Root mean square error, Index of agreement, Nash Sutcliffe Efficiency, and Percentage deviation in peak as defined by equation (3), (4), (5), (6), and (7).

i) Correlation coefficient (CC):

$$
\mathrm{CC}=\frac{\sum_{\mathrm{i}=1}^{\mathrm{n}}\left(\mathrm{O}_{\mathrm{i}}-\text { Oavg }\right)\left(\mathrm{P}_{\mathrm{i}}-\text { Pavg }\right)}{\sqrt{\sum_{\mathrm{i}=1}^{\mathrm{n}}\left(\mathrm{O}_{\mathrm{i}}-\text { Oavg }\right)^{2}} \sqrt{\sum_{\mathrm{i}=1}^{\mathrm{n}}\left(\mathrm{P}_{\mathrm{i}}-\mathrm{Pavg}\right)^{2}}}
$$


ii) Root mean square error (RMSE):

$\operatorname{RMSE}=\sqrt{\frac{1}{n} \sum_{i=1}^{n}\left(O_{i}-P_{i}\right)^{2}}$

iii) Index of agreement (d):

$\mathrm{d}=1-\frac{\sum_{i=1}^{n}\left(\boldsymbol{O}_{i}-\boldsymbol{P}_{i}\right)}{\sum_{i=1}^{n}\left[\left|\boldsymbol{O}_{i}-\boldsymbol{O}_{\text {avg }}\right|+\left|\boldsymbol{P}_{i}-\boldsymbol{O}_{\text {avg }}\right|\right]^{2}}$

iv) Nash Sutcliffe Efficiency (NSE):

$\mathrm{NSE}=1-\frac{\sum_{i=1}^{n}\left(\boldsymbol{O}_{i}-\boldsymbol{P}_{i}\right)}{\sum_{i=1}^{n}\left(\boldsymbol{O}_{i}-\boldsymbol{O}_{\text {avg }}\right)^{2}}$

v) Percentage deviation in peak (\% deviation):

$\%$ deviation $=\frac{\left(P_{P}-O_{P}\right)}{O_{P}}$

Where $\mathrm{O}_{\mathrm{i}}$ is the observed water level at the ith hour, $\mathrm{P}_{\mathrm{i}}$ the predicted or simulated water level, $\mathrm{n}$ is total number of observations; $\mathrm{O}_{\text {avg }}$ is average of observed water level; $P_{P}$ is the predicted peak and $O_{P}$ is the observed peak of water level.

\section{RESULTS AND DISCUSSION}

\section{Calibration of the model using DEM derived cross-sections of $30 \mathrm{~m}$ and $90 \mathrm{~m}$ resolutions}

For simulating the water depth at various sections of the Krishna River, the model is calibrated for the period of June to November 2006. While performing the dry run for the model for the specified period, Manning's roughness coefficient was varied from 0.03 to 0.05 (Chow, 1959). The calibration was initiated from 0.03 and the final value of Manning's roughness coefficient was chosen based upon the agreement of the simulated values with observed values. The calibrated values were found in reasonable agreement 
with the observed values for both DEM $30 \mathrm{~m}$ and $90 \mathrm{~m}$ resolution. The calibrated values were then used for the validation as discussed in the next section.

\section{Validation of the model using DEM derived cross-sections of $30 \mathrm{~m}$ and $90 \mathrm{~m}$ resolutions}

The calibrated MIKE HYDRO River model setup was validated for the 2009 flood event. The calibrated values were used to validate the model. All the model simulating parameters were kept the same, which resulted in predicted values close to the observed values, for the 2006 flood event, except the boundary conditions were changed to the 2009 flood event. Model validation was performed by comparing the observed water levels at K. Agraharam station with the simulated water levels, as the data is available for this station. The comparison of

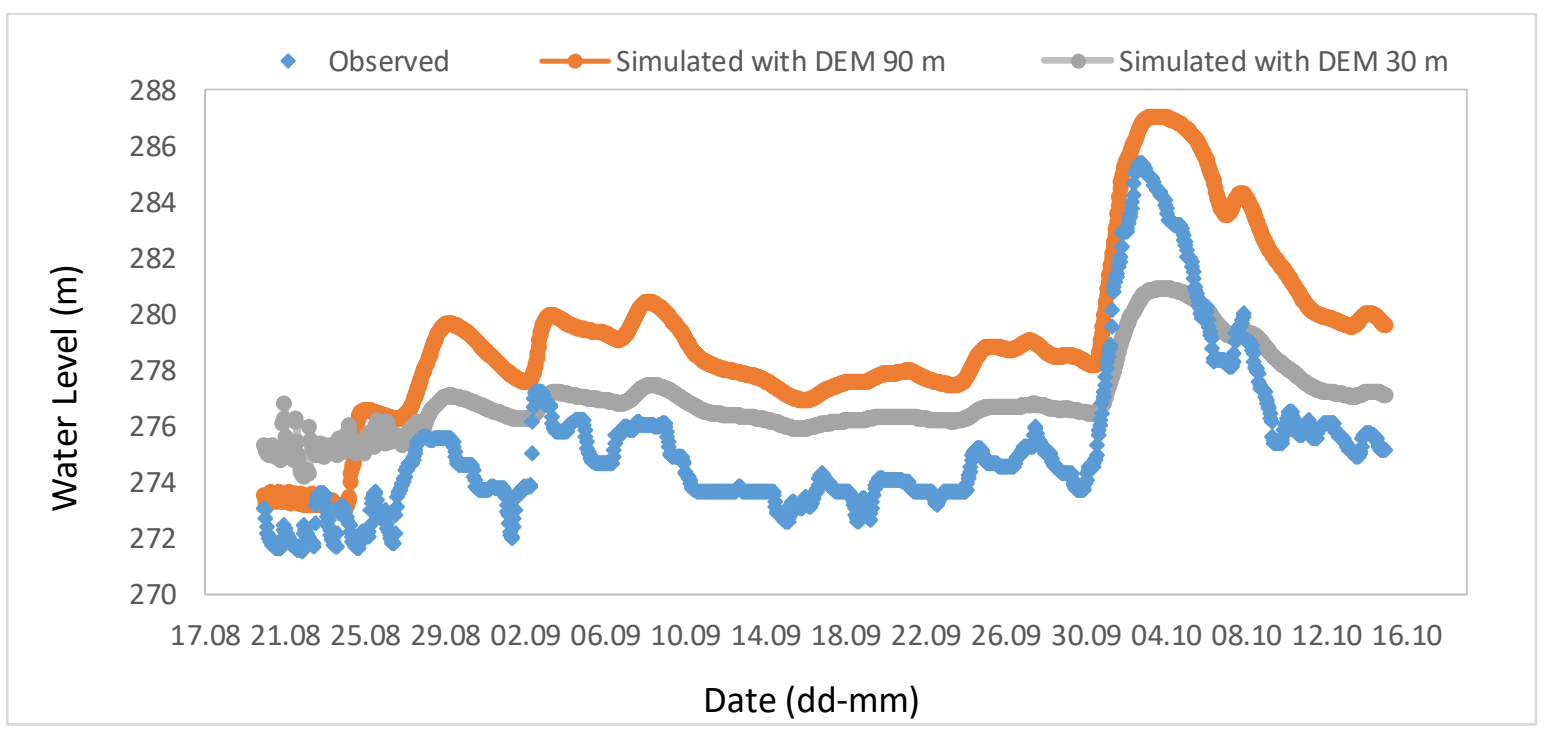

Figure 3. Observed and simulated water levels for the validation year 2009 for SRTM $30 \mathrm{~m}$ and SRTM 90m (Before Cross-Section Correction) 
Table 1. Performance indices for validation year 2009 for SRTM $30 \mathrm{~m}$ and SRTM $90 \mathrm{~m}$ (Before Cross-Section Correction)

\begin{tabular}{cccccc}
\hline SRTM DEM & CC & RMSE & $\mathrm{d}$ & NSE & $\begin{array}{c}\text { Percentage deviation } \\
\text { in peak }(\%)\end{array}$ \\
\hline $30 \mathrm{~m}$ & 0.92 & 2.32 & 0.78 & 0.33 & -1.55 \\
\hline $90 \mathrm{~m}$ & 0.92 & 3.84 & 0.74 & -0.92 & 0.60 \\
\hline
\end{tabular}

observed water levels with the simulated values for the $30 \mathrm{~m}$ and $90 \mathrm{~m}$ resolution DEM is shown in Figure 3. The performance indices for the validation event are tabulated in Table 1. It is observed that the results obtained by the model with $90 \mathrm{~m}$ resolution DEM are in continuous over prediction with the observed values. With $30 \mathrm{~m}$ resolution DEM also the simulated values are in overprediction but the peak value was underestimated as revealed by the performance indices tabulated in Table 1 . The simulated peak value as obtained by $90 \mathrm{~m}$ resolution DEM over predicts with a percentage deviation of 0.6 (Table 1). The NSE value for the model was not found in a good range (Pan et al., 2013) which indicates that the model does not perform well with the DEM extracted cross-sections. The overpridiction of flows are due to extracted cross-sections from DEMs.

\section{New Procedure for Modification in DEM Dervied Cross Sections}

A cross-section at K-Agraharam station was available for comparison to the DEM extracted cross-section. The measured cross-section at K. Agraharam was compared with the corresponding DEM-extracted cross-sections. The cross-sections extracted from both DEMs have elevations greater than the actual cross-section (Figure 4a). The unmodified DEM-extracted cross-sections results in overestimation of simulated water level because of their higher elevation values. Thus performance indices can be improved further. To 
reduce the error with respect to the actual cross-section, the extracted cross-sections are required to be modified. Pramanik et al. (2010) proposed error analysis methodology based on data of spot heights taken from the topographic map and the deviations of the elevation values of the DEM from their respective spot heights. They used root mean square error(RMSE) of DEM for different elevation ranges to modify the cross section. The said procedure is cumbersome and requires more data. Thus, an easier methodology is propsed to improve the performance indices of $1 \mathrm{D}$ modeling.

In Figure 4a the best fit lines are drawn for each cross-section using second degree polynomial. The best fit line equations for actual cross-section of K. Agraharam, derived cross-section of K. Agraharam from $30 \mathrm{~m}$ resolution DEM and derived cross-section of K.Agraharam from $90 \mathrm{~m}$ resolution DEM are given in equations (8), (9) and (10), respectively. The best-fit curves are shown in Figure $4 a$.

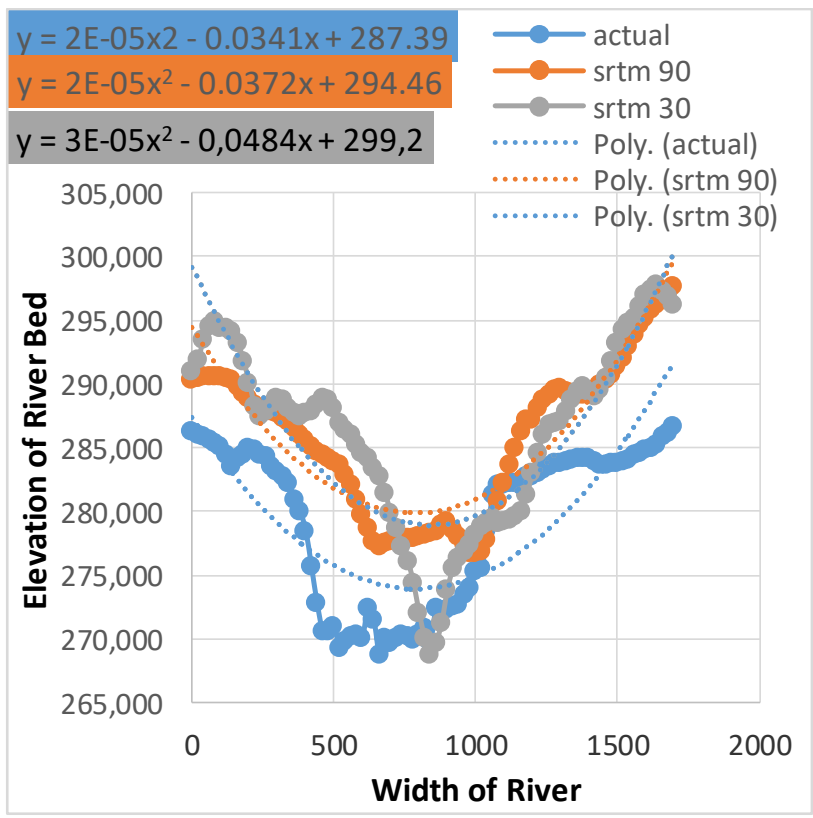

(a)

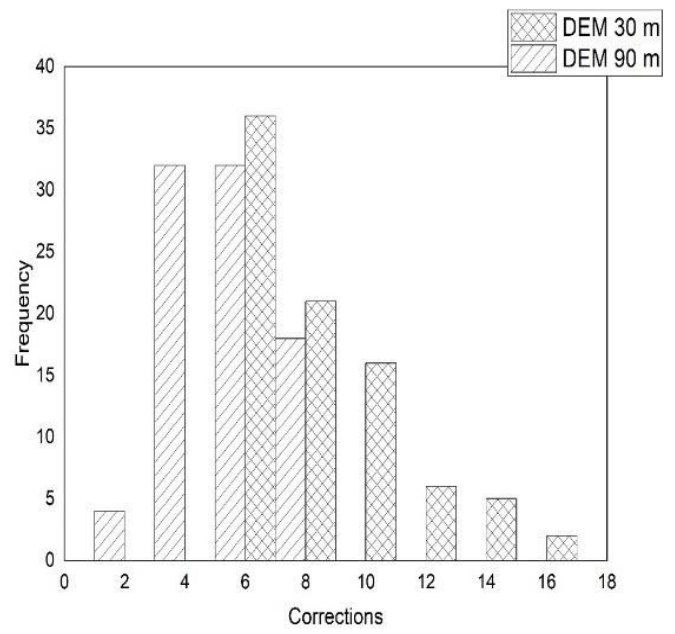

(b) 

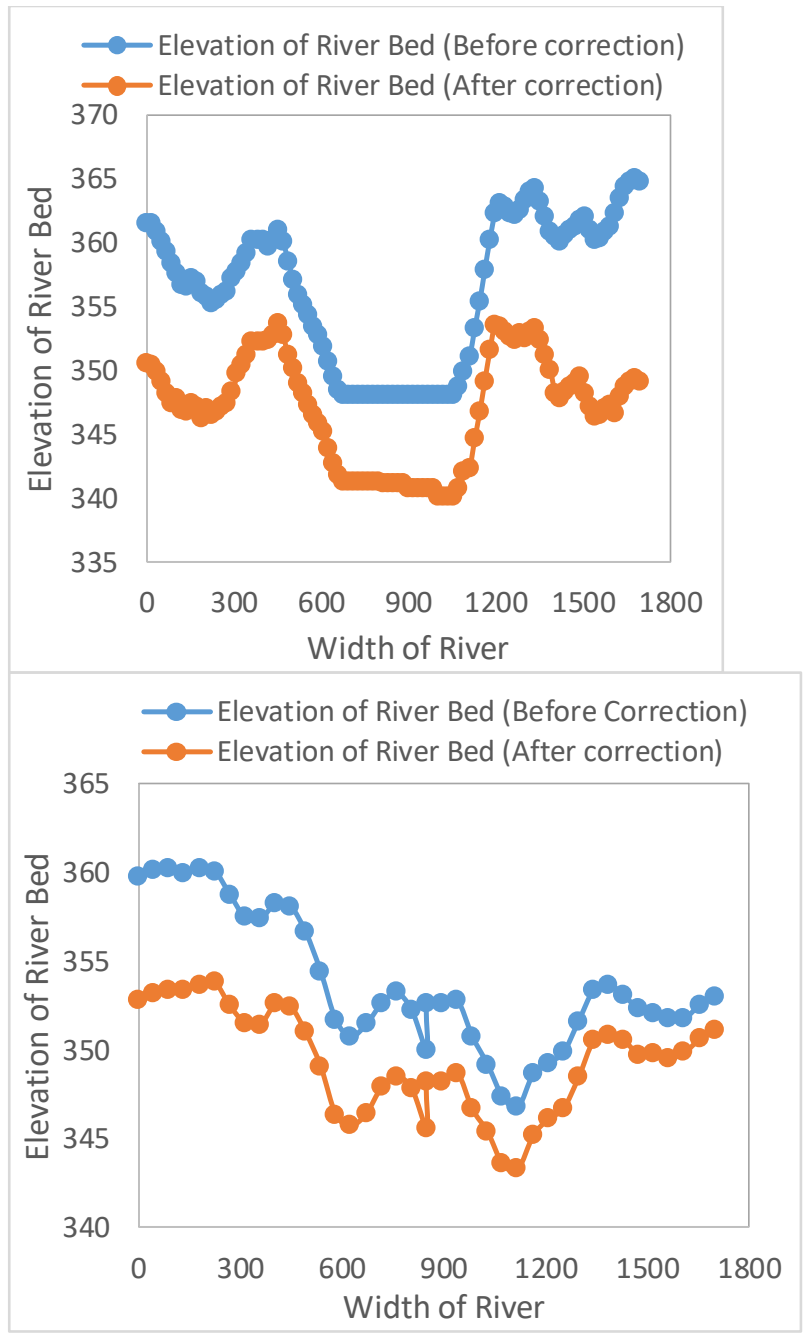

(c)

(d)

Figure 4. Cross- Section Corrections: (a) Cross-sections comparison derived from DEM 30 $\mathrm{m}$ and $90 \mathrm{~m}$ resolutions with actual cross-section at K. Agraharam , (b) Correction Frequency plot for DEM $30 \mathrm{~m}$ and $90 \mathrm{~m}$, (c) Cross-Section at Huvinhedgi for SRTM $30 \mathrm{~m}$, (d) Cross-Section at Huvinhedgi for for SRTM $90 \mathrm{~m}$
$\mathrm{y}$
$=$
$2 \mathrm{E}-05 \mathrm{x}^{2}$
$0.0341 \mathrm{x}$
$+$
287.39

(8)

$\begin{array}{llllll}\mathrm{y} & = & 3 \mathrm{E}-05 \mathrm{x}^{2} & - & 0.0484 \mathrm{x} & +\end{array}$

(9)

$\&$ 
$\begin{array}{llllll}\mathrm{y} & = & 2 \mathrm{E}-05 \mathrm{x}^{2} & - & 0.0372 \mathrm{x} & +\end{array}$ (10)

The required corrections in DEM derived cross sections are obtained by subtracting Eq (8) from Eq (9) and Eq (10.) The river width at K. Agraharam was divided in $100 \mathrm{~m}$ intervals through out in its total width of $1700 \mathrm{~m}$. The average bed level elevation correction was calculated in the first, second, third \& so on in $100 \mathrm{~m}$ intervals . The average bed level elevation correction ranged beween $1.92 \mathrm{~m}$ to $6.88 \mathrm{~m}$ in derived $90 \mathrm{~m}$ resolution DEM cross- section. On the other hand, the average bed level elevation correction ranged beween $6.73 \mathrm{~m}$ to $15.64 \mathrm{~m}$ in derived $30 \mathrm{~m}$ resolution DEM cross- section. Figure 4 (b) shows the correction frequency plot for the models with $30 \mathrm{~m}$ and $90 \mathrm{~m}$ resolution DEM.

The average elevation corrections at various sections of width as discussed above at K. Agraharam are applied to all the generated cross-sections at the interval of $2000 \mathrm{~m}$ up to upstream boundaries. These modified cross-sections are then used for the simulation of river flow. Figure 4c and 4d show modified sample cross-section at Huvinhedgi for SRTM $30 \mathrm{~m}$ and $90 \mathrm{~m}$ resolutions, respectively.

\section{Calibration of model after correcting derived cross-sections from $30 \mathrm{~m}$ and $90 \mathrm{~m}$ resolution DEM}

The modified cross-sections are used for simulations of water depth at various sections of the Krishna River and Bhima River. Manning's roughness coefficient is used as simulating parameter and is chosen based upon the best agreement of the simulated values with observed values. 


\section{Validation of model after correcting derived cross-sections from $30 \mathrm{~m}$ and $90 \mathrm{~m}$ resolution DEM}

The calibrated MIKE HYDRO River model setup is validated for the 2009 flood event with modified cross-sections. The comparison of observed water levels with the simulated water levels for the $30 \mathrm{~m}$ and $90 \mathrm{~m}$ resolution DEM is shown in Figure 5. The model performace indices are tabulated in Table 2. It is observed that the results obtained by the model with $30 \mathrm{~m}$ and $90 \mathrm{~m}$ resolution DEM are in better agreement with the observed values. This can be improved further, if more cross sections of river are known. The model with $90 \mathrm{~m}$ resolution DEM is found to perform better than the model with $30 \mathrm{~m}$ resolution DEM as revealed by the performance indices (Table 2). A similar kind of trend has been observed in previous studies (Tehrani et al., 2020; Timbadiya et al., 2014; Patro et al.,2009). The underestimation of peak values can be due to negligence of the confluence of the Krishna River with the Tungabhadra River. The data insufficiency for the peak values can also cause the underestimation of the peak values, and hence further study is required to understand the peak value underestimation.

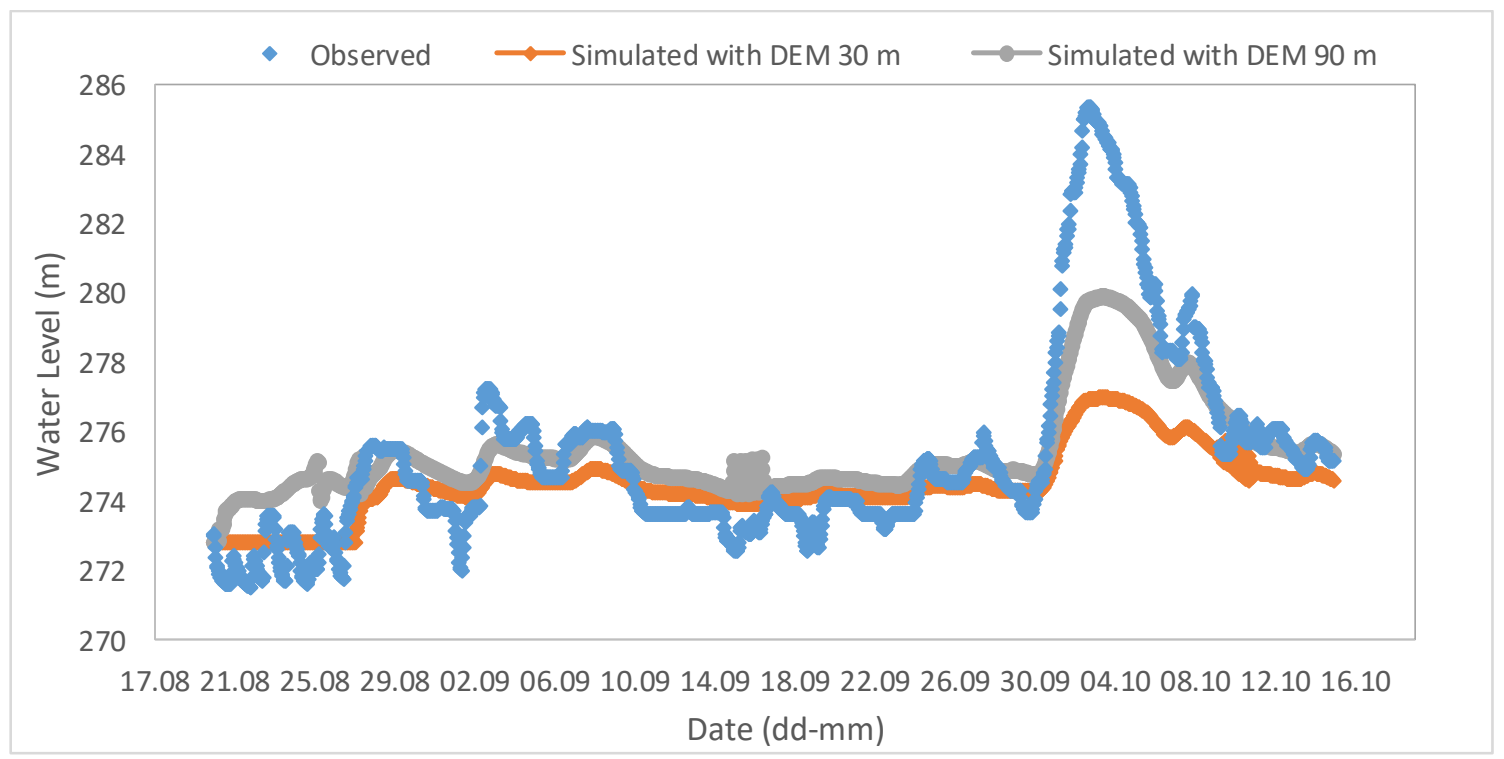


Figure 5. Observed and simulated water levels for the validation event 2009 for SRTM 30 $\mathrm{m}$ and SRTM $90 \mathrm{~m}$ (After Cross-Sections Correction)

Table 2. Performance indices for validation year 2009 for SRTM 30 m and SRTM $90 \mathrm{~m}$ (After Cross-Section Correction)

\begin{tabular}{cccccc}
\hline SRTM DEM & CC & RMSE & $\mathrm{d}$ & NSE & $\begin{array}{c}\text { Percentage deviation } \\
\text { in peak }(\%)\end{array}$ \\
\hline $30 \mathrm{~m}$ & 0.92 & 2.08 & 0.72 & 0.48 & -2.93 \\
\hline $90 \mathrm{~m}$ & 0.95 & 1.51 & 0.88 & 0.73 & -1.9 \\
\hline
\end{tabular}

The results of the MIKE HYDRO River model are displayed in MIKE View. The water surface profile of the Krishna River from Huvinhedgi to K.Agrahram station for $30 \mathrm{~m}$ and $90 \mathrm{~m}$ resolution DEM is presented in Figures 6 (a) and (b) respectively. The time taken for simulation with $30 \mathrm{~m}$ resolution DEM was higher than with $90 \mathrm{~m}$ resolution DEM. The peak time error (PTE) (Zhang et al., 2020) predicted with resolutions of $30 \mathrm{~m}$ and $90 \mathrm{~m}$ DEMs is -0.75 day, which indicates that the time of occurrence of the peak with both the models is same.

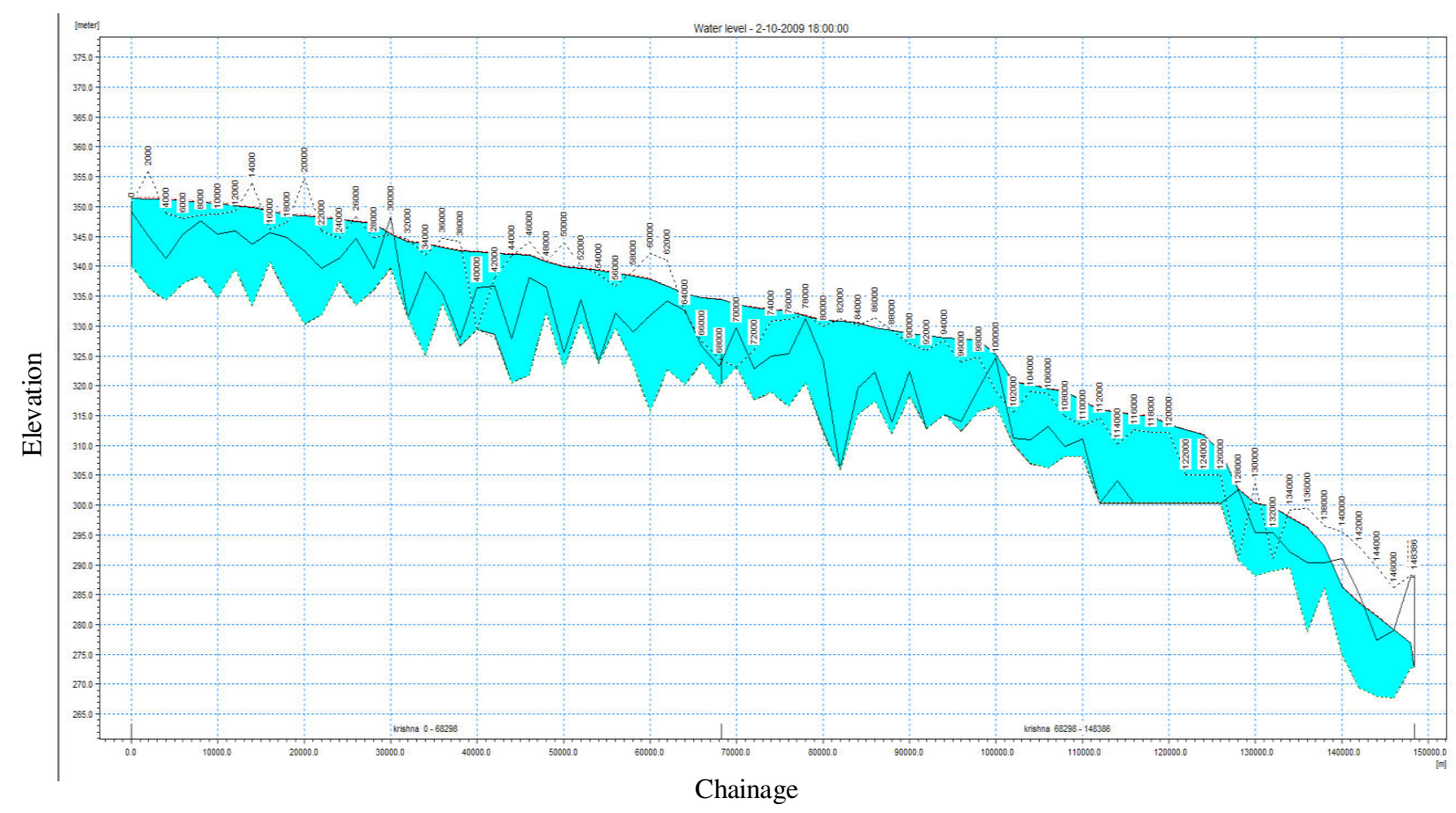


(a)

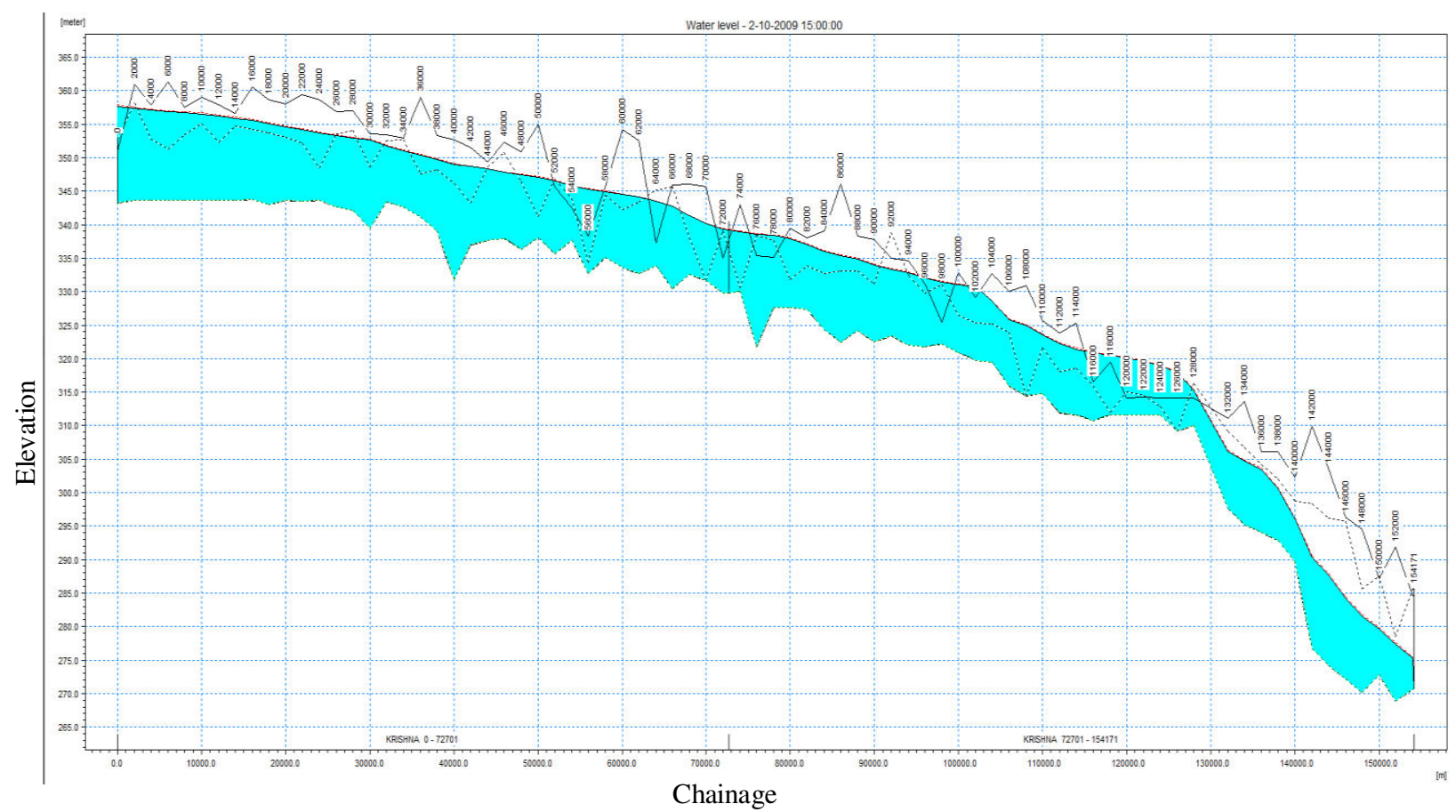

(b)

Figure 6 Water Surface Profiles: (a) for model with DEM 30 m resolution, (b) for model with DEM 90 m resolution

\section{CONCLUSIONS}

In the present study, the MIKE HYDRO River model is set up and run for the 2006 and 2009 monsoon period for the Krishna (from Huvindhegdi to K. Agraharam gauging station) and Bhima River ( from Yadgir to the confluence with Krishna River) using $30 \mathrm{~m}$ and $90 \mathrm{~m}$ DEM resolutions. The following conclusions are drawn:

- Manning's coefficient is used as the simulating parameter to perform the hydrodynamic modeling of the river reach. The global Manning's rougness coefficient value of 0.03 is found to be most appropriate as the results obtained with this value were in best agreement with the observed data 
- $\quad$ The CC, RMSE, d, NSE \& Percentage deviation in peak (\%) values for predicted river flow obtained form $30 \mathrm{~m}$ resolution SRTM DEM are 0.92, 2.32, 0.78, 0.33 and -1.55 , respectively. The CC, RMSE, d, NSE \& Percentage deviation in peak (\%) values for predicted river flow obtained form 90 m resolution SRTM DEM are 0.92, 3.84, 0.74, -0.92 and 0.60. The CC values are same for both DEMs, however, other parameters are better for 30 m resolution SRTM DEM. Thus, the model performance on unmodified DEM-extracted cross-sections of river from SRTM DEM $30 \mathrm{~m}$ resolution is better in comparison to SRTM DEM 90 m resolution.

- The cross-sections extracted from both DEMs have elevations greater than the known cross-section of the station, therefore unmodified DEM-extracted cross-sections results in overestimation of simulated water level because of their higher elevation values

- A new methodology for modification in SRTM Dervied Cross Sections is developed which is easier to apply and requires only one known cross- section of river.

- This method is computationally efficient as compared to the method adopted by Pramanik et al. (2010) in which data requirements are high.

- The model performance with modified DEM-extracted cross-sections of river improves as the CC, RMSE, d, NSE \& Percentage deviation in peak (\%) values for SRTM DEM 30 m resolution are $0.92,2.08,0.72,0.48$ and -2.93 . The CC, RMSE, d, NSE \& Percentage deviation in peak (\%) values for SRTM DEM $90 \mathrm{~m}$ resolution are 0.95, 1.51, $0.88,0.73$ and -1.9 .

- The model performance with modified DEM-extracted cross-sections of river SRTM DEM 90 m resolution is better in comparison to SRTM DEM 30 m resolution. 
- $\quad$ The modified DEM-extracted cross-sections results in closer estimate of simulated water level.

- $\quad$ The computational cost for $90 \mathrm{~m}$ resolution DEMs is $5 \%$ less in comparison to 30 m.

\section{Acknowledgement}

Authors are extremely thankful to the office of the Chief Engineer, Krishna \& Godavari Basin Organisation, Central Water Commission, Krishna Godavari Bhavan, Hyderabad, Telangana for providing data.

\section{Declarations:}

Ethical Approval: The authors are responsible for the integrity of the manuscript (including ethics, data handling, reporting of results, and study conduct).

Consent to Participate: Not applicable.

Consent to Publish: All the authors have approved the submission and consented for publication.

Authors Contributions: Conceptualization: [Komal Vashist, K. K. Singh]; Modeling simulation and investigation: [Komal Vashist, K. K. Singh]; Writing - original draft preparation: [Komal Vashist]; Writing - review and editing: [K. K. Singh]; and Supervision: [K. K. Singh].

Funding: No funding was received to assist with the preparation of this manuscript. Competing Interest: The authors declare that they have no conflicts of interest.

Availability of Data and Material: Data, that support the findings of this study are available from the corresponding author. 
Code Availability: Not applicable 


\section{REFERENCES}

Abbott, M. B., \& Ionescu, F. (1967). On The Numerical Computation Of Nearly Horizontal Flows. Journal of Hydraulic Research, 5(2), 97-117 https://doi.org/10.1080/00221686709500195

Afshari, S., Tavakoly, A. A., Adnan, M., Zheng, X., Follum, M. L., Omranian, E., \& Fekete, B. M. (2018). Comparison of new generation low-complexity flood inundation mapping tools with a hydrodynamic model. Journal of Hydrology, 556, 539-556. https://doi.org/10.1016/j.jhydrol.2017.11.036

APWRDC, Managing historic floods in Krishna River basin October 2009 Andhra Pradesh India 132p.

Bates, P. D., Anderson, M. G., \& Hervouet, J. M. (1995). Initial comparison of two twodimensional finite element codes for river flood simulation. Proceedings of the Institution of Civil Engineers: Water, Maritime and Energy, 112(3), 238-248. https://doi.org/10.1680/iwtme.1995.27886

Bates, P. D., \& De Roo, A. P. J. (2000). A simple raster-based model for flood inundation simulation. Journal of Hydrology, 236(1-2), 54-77. https://doi.org/10.1016/S00221694(00)00278-X

Bates, P.D., 2004. Remote sensing and flood inundation modelling. Hydrological processes, 18(13), pp.2593-2597. https://doi.org/10.1002/hyp.5649

Chen, W.-B., \& Liu, W.-C. (2017). Modeling the Influence of River Cross-Section Data on a River Stage Using a Two-Dimensional/Three-Dimensional Hydrodynamic Model. Water, 9(3), 203. https://doi.org/10.3390/w9030203 
Chow, V. T. (1959). Open-channel hydraulics. International student edition. McGraw-Hill Civil Engineering Series. McGraw-Hill: Tokyo.

Cook, A., \& Merwade, V. (2009). Effect of topographic data, geometric configuration and modeling approach on flood inundation mapping. Journal of Hydrology, 377(1-2), 131142. https://doi.org/10.1016/j.jhydrol.2009.08.015

DHI. (2017). MIKE 11 A Modelling System for Rivers and Channels Reference Manual.

DHI (2017). MIKE HYDRO River User Guide.

Fan, Y., Ao, T., Yu, H., Huang, G., \& Li, X. (2017). A coupled 1D-2D hydrodynamic model for urban flood inundation. Advances in Meteorology, 2017, 1-12. https://doi.org/10.1155/2017/2819308

Farooq, M., Shafique, M., \& Khattak, M. S. (2019). Flood hazard assessment and mapping of River Swat using HEC-RAS 2D model and high-resolution 12-m TanDEM-X DEM (WorldDEM). Natural Hazards, 97(2), 477-492. https://doi.org/10.1007/s11069-01903638-9

Fewtrell, T. J., Bates, P. D., Horritt, M., \& Hunter, N. M. (2008). Evaluating the effect of scale in flood inundation modelling in urban environments. 5118(November), 51075118. https://doi.org/10.1002/hyp

Geravand, F., Mossa, S., \& Ataie-ashtiani, B. (2020). Influence of river cross-section data resolution on flood inundation modeling : Case study of Kashkan river basin in western Iran. Journal of Hydrology, 584(December 2019), 124743. https://doi.org/10.1016/j.jhydrol.2020.124743

Horritt, M. S., \& Bates, P. D. (2001). Predicting floodplain inundation: raster-based 
modelling versus the finite-element approach. Hydrological Processes, 15(5), 825-842. https://doi.org/10.1002/hyp.188

Horritt, M. S., \& Bates, P. D. (2002). Evaluation of 1D and 2D numerical models for predicting river flood inundation. Journal of Hydrology, 268(1-4), 87-99. https://doi.org/10.1016/S0022-1694(02)00121-X

Horritt, M.S., Bates, P.D. and Mattinson, M.J., 2006. Effects of mesh resolution and topographic representation in 2D finite volume models of shallow water fluvial flow. Journal of Hydrology, 329(1-2), pp.306-314.

Hunter, N. M., Bates, P. D., Horritt, M. S., \& Wilson, M. D. (2007). Simple spatiallydistributed models for predicting flood inundation: A review. Geomorphology, 90(3-4), 208-225. https://doi.org/10.1016/j.geomorph.2006.10.021

Kadam, P., \& Sen, D. (2012). Flood inundation simulation in Ajoy River using MIKEFLOOD. ISH Journal of Hydraulic Engineering, 18(2), 129-141. https://doi.org/10.1080/09715010.2012.695449

Lin, B., Wicks, J. M., Falconer, R. A., \& Adams, K. (2006). Integrating 1D and 2D hydrodynamic models for flood simulation. Proceedings of the Institution of Civil Engineers: $\quad$ Water $\quad$ Management, $159(1), \quad$ 19-25. https://doi.org/10.1680/wama.2006.159.1.19

Marks, K. and Bates, P., 2000. Integration of high-resolution topographic data with floodplain flow models. Hydrological processes, 14(11-12), pp.2109-2122.

Mignot, E., Paquier, A., \& Haider, S. (2006). Modeling floods in a dense urban area using 2D shallow water equations. Journal of Hydrology, 327(1-2), 186-199. 
https://doi.org/10.1016/j.jhydrol.2005.11.026

Nkwunonwo, U. C., Whitworth, M., \& Baily, B. (2020). A review of the current status of flood modelling for urban flood risk management in the developing countries. Scientific African, 7, e00269. https://doi.org/10.1016/j.sciaf.2020.e00269

Omer, C. R., Nelson, E. J., \& Zundel, A. K. (2003). Impact of varied data resolution on hydraulic modeling and floodplain delineation. Journal of the American Water Resources Association, 39(2), 467-475. https://doi.org/10.1111/j.17521688.2003.tb04399.x

Padmanabhan, G. (2009). India: Floods in Andhra Pradesh and Karnataka situation report No. 1 .

Pan, T., Wu, S., Dai, E., \& Liu, Y. (2013). Estimating the daily global solar radiation spatial distribution from diurnal temperature ranges over the tibetan plateau in China. Applied Energy, 107, 384-393. https://doi.org/10.1016/j.apenergy.2013.02.053

Patro, S., Chatterjee, C., Mohanty, S., Singh, R., \& Raghuwanshi, N. S. (2009). Flood inundation modeling using MIKE FLOOD and remote sensing data. Journal of the Indian Society of Remote Sensing, 37(1), 107-118. https://doi.org/10.1007/s12524-0090002-1

Patro, Shivananda, Chatterjee, C., Singh, R., \& Raghuwanshi, N. S. (2009). Hydrodynamic modelling of a large flood-prone river system in India with limited data. Hydrological Processes, 23(19), 2774-2791. https://doi.org/10.1002/hyp.7375

Pramanik, N., Panda, R. K., \& Sen, D. (2010). One dimensional hydrodynamic modeling of river flow using DEM extracted river cross-sections. Water Resources Management, 
24(5), 835-852. https://doi.org/10.1007/s11269-009-9474-6

Gesch, D.B., Oimoen, M.J. and Evans, G.A., (2014). Accuracy assessment of the US Geological Survey National Elevation Dataset, and comparison with other large-area elevation datasets: SRTM and ASTER (Vol. 1008). US Department of the Interior, US Geological Survey

Sahoo, S. N., \& Sreeja, P. (2017). Development of Flood Inundation Maps and Quantification of Flood Risk in an Urban Catchment of Brahmaputra River. ASCEASME Journal of Risk and Uncertainty in Engineering Systems, Part A: Civil Engineering, 3(1), 1-11. https://doi.org/10.1061/AJRUA6.0000822

Tehrani, J. M., Helfer, F., Zhang, H., Jenkins, G., \& Yu, Y. (2020). Hydrodynamic modelling of a flood-prone tidal river using the 1D model MIKE HYDRO River: calibration and sensitivity analysis. Environmental Monitoring and Assessment, 192(2), 97. https://doi.org/10.1007/s10661-019-8049-0

Teng, J., Jakeman, A. J., Vaze, J., Croke, B. F. W., Dutta, D., \& Kim, S. (2017). Environmental Modelling \& Software Flood inundation modelling: A review of methods, recent advances and uncertainty analysis. Environmental Modelling and Software, 90, 201-216. https://doi.org/10.1016/j.envsoft.2017.01.006

Timbadiya, P. V, Patel, P. L., \& Porey, P. D. (2014). One-dimensional hydrodynamic modelling of flooding and stage hydrographs in the Lower Tapi river in India. Current Science, 106(5), 708-716. https://doi.org/10.18520/cs/v106/i5/708-716

Werner, M. G. F. (2001). Impact of grid size in GIS based flood extent mapping using a 1D flow model. Physics and Chemistry of the Earth, Part B: Hydrology, Oceans and 
Atmosphere, 26(7-8), 517-522. https://doi.org/10.1016/S1464-1909(01)00043-0

Wright, N. G., Villanueva, I., Bates, P. D., Mason, D. C., Wilson, M. D., Pender, G., \& Neelz, S. (2008). Case Study of the Use of Remotely Sensed Data for Modeling Flood Inundation on the River Severn , $U$. $K$. 134(May), 533-540. https://doi.org/10.1061/(ASCE)0733-9429(2008)134

Yu, D. and Lane, S.N., 2006. Urban fluvial flood modelling using a two-dimensional diffusion-wave treatment, part 1: mesh resolution effects. Hydrological Processes: An International Journal, 20(7), pp.1541-1565.

Zhang, Y., Zhou, J., \& Lu, C. (2020). Integrated Hydrologic and Hydrodynamic Models to Improve Flood Simulation Capability in the Data-Scarce Three Gorges Reservoir Region. Water, 12(5), 1462. https://doi.org/10.3390/w12051462 